\title{
Flu Days
}

\section{By Peter Makuck}

Shivering, you drag yourself, as if gun-shot, to the living room,

to the old movie channel, to a Bogart festival,

your mind fogged over (like the street on the screen)

edging toward feverish sleep when Bogey snarls

at Ida Lupino:

"Of all the 14-carat saps..."

Hours later when you wake, he's smacking Peter Lorre:

"When you're slapped, you'll take it and like it!"

And as if cuffed, you black out, head pounding, and come to

upon Ingrid Bergman and "You must remember this," before fading again, then back

to Bogey hacked to death

by Bedoya's machete, all that gold dust blown away

with the whole bloody day, everything gone-gone black

as your living room windowsthose previews of The Big Sleep.

Poem reprinted from Mandatory Evacuation, (C2016, by Peter Makuck, courtesy of BOA Editions, Ltd., Rochester, NY, USA;

http://www.boaeditions.org.

Peter Makuck is a writer, essayist, and poet and

Distinguished Professor Emeritus at East Carolina University,

Greenville, North Carolina; email: peter@makuck.com

DOI: http://dx.doi.org/10.3201/eid2212.AD2212 